\title{
FAMILY BUSINESSES: A DIAGNOSIS AND SELF THERAPY MODEL
}

\author{
Kerstin SIAKAS ${ }^{5}$, Spyros VASSILIADIS, Errikos SIAKAS
}

\begin{abstract}
Family businesses are complex systems which require good strategy, leadership, and committed personnel in order to thrive. Compared to other businesses family businesses are characterized by two dynamic and sometimes conflicting reference systems, the family (the emotional) and the company (the professional). Succession is mentioned in the literature as one of the four main categories of problems, along with problems of strategy, of the conflicts that can arise between family members and the problems of the daily management. The management of conflict and communication frequently determine the effectiveness of the family business.
\end{abstract}

The "Family Business in the New Economy: How to Survive and Develop" (FAMBUS) project aims to develop a model for diagnosis and self-therapy (diagnostics - therapy, including conflict resolution, modernization, adoption to environment, to globalization etc.). The model aims to promoting healthy personal relationships and building high performing teams, as well as to serve as an outside resource that brings objectivity and direction to a certain situation in family businesses. It may unfold unfinished or unspoken issues and help the family business members to work toward their own unique solutions.

The creation of the model is based on the results of the quantitative study (a survey comprising a structured questionnaire completed by 200 Finnish and Greek family businesses) and qualitative study (Personal site visits and interviews comprising 20 interviews in both Finland and Greece) for obtaining deeper understanding of the research problem and to support the design of the diagnosis and self-therapy model.

The most important contribution of this work is anticipated to be the novel family business diagnosis and self-therapy model and subsequent electronic tool in three languages, English, Finnish and Greek, for identification of potential problem areas and potential activities for their solutions. The aim of the model is to aid family businesses to avoid difficulties at an early stage and to serve as a self-therapy model.

\section{KEY WORDS}

Family Businesses, Diagnosis and Self Therapy Model, Sustainable development, the FAMBUS project, Greece, Finland

5 Correspondence address: Kerstin, Siakas, title: professor; telephone: +302310013296; fax:+302310444698; email address: siaka@it.teithe.gr, Alexander Technological Educational Institute of Thessaloniki, Department of Informatics, P. O. Box 141, GR-57400 Thessaloniki, Greece, URL: www.teithe.gr/ siaka 


\section{JEL CLASSIFICATION}

M21

\section{INTRODUCTION}

Family businesses have strong historical presence and extensive prevalence in today's society and economy. In fact, the family is the oldest and longest running social unit in our world. Families, sustained themselves by self-sufficient means long before commerce began (Ponzetti, 2003). Today family businesses contribute significantly to economic and social sustainability and welfare and the impact on local and national economies is huge. Family businesses are the majority in most economies worldwide (Brice and Richardson, 2009; Villalonga and Amit, 2010). Nevertheless, the family business, as a field of academic study, is recent and still emerging (Heck and Stafford, 2001; Heck and Trent, 1999). Scholars have begun to recognize the importance of family businesses and their connection to entrepreneurship (Rogoff and Heck, 2003; Zachary and Mishra, 2011). Conceptually, after years of studies centered on the entrepreneur as an individual, the entrepreneur is re-examined through a wider lens. Today a broader and more comprehensive view of entrepreneurial activity through the role played by the family system is recognized (Cramton, 1993; Danes et al., 2008, 2009).

There is no common, widespread definition or understanding of what constitutes a "family business" that is generally applied across Europe for political, economic as well as academic purposes at the same time (Mandl, 2008). This makes it difficult to provide

i. a valid characterization of family businesses;

ii. a valid analysis of their economic importance;

iii. potential (public) support instruments for family businesses to overcoming the challenges they are confronted with in their daily activities.

Family businesses compared to other businesses are characterized by two dynamic and sometimes conflicting reference systems, the family (the emotional) and the company (the professional). The dynamics and characteristics of the family, that owns the business, have been investigated only marginally (Michael-Tsabari and Lavee (2012). Family members may have competing goals and values, which may spring from complex conflicts and family dynamics that arise from a psychosocial history of the family (Dyer, 2006). Many of the family business members may also have several roles (e.g., owner, employee, parent, child, sibling) causing role ambiguity and interrole conflict (Sundaramurthy and Kreiner, 2008).

The family unit brings together and creates the forces enabling the emerging and sustained entrepreneurial behavior in family businesses (Zachary, 2011). The conceptualization of the family business must include a multidisciplinary and comprehensive perspective of the dynamic and complex phenomenon of business that is owned and operated mainly by family members. The importance of the family system and the development of the company are essential in our understanding of the current state conceptualization and theory building. Hence, the role of the family system in the conceptualization of the family business / family entrepreneurship is critical to our understanding of how family businesses emerge and sustains through their interactions with the environmental contexts in which they operate.

Historically, the capability to grow in size and strengthen in market power has been a process of 
evolution of the family business. Survival is considered the most significant manifestation of success for a firm, in particular for a family firm (Colli, 2012). The survival of a family-owned firm confirms the persistence of control by the same family over time. Longevity on the contrary is measured in terms of the age of the enterprise, independently of its ownership structure.

The failure rate of family-owned business to pass successfully from generation to generation is around 70 per cent (Tucker, 2011) and the professional advices have to take into account the unique issues facing the family in business.

Only $30 \%$ of family businesses have a second-generation perspective. Many researchers have studied the succession process in family businesses as well as the reasons why there is such a high rate of failure. The predominant approach among researchers is that there is strong connection between planning and successful transfer of family business. Planning seems to be the magic formula. According to Lansberg (1988) "the lack of succession planning has be identified as one of the most important reasons why many first-generation family firms do not survive their founders". Recently a new approach has emerged. Several researchers (Aronoff, Astrachan, Keating \& Little) have highlighted that there is no connection between planning and successful succession. Instead, the succession process requires the perspective of a multigeneration time frame. In between, Lambrecht and Donckels (2006) argue that the transfer of the family business to the next generation is "a lifelong, continuing process" in which planning is an intrinsic part. In other words, planning is a necessary but not a sufficient condition for a successful transfer of the family business to the next generations.

Due to the importance of family businesses in the economies of nations it is important that they receive as much support a possible. There are three reasons the family business consulting (supporting) experience is different from consulting in other businesses, namely:

i. Consulting family businesses is more personal than consulting businesses in general due to the two conflicting reference systems;

ii. Family dynamics, emotions and conflict seem to contaminate the business environment;

iii. The balance between the family and the business concerns is fragile. This area includes such issues as:

- The presence of family members in operating positions for which they are not qualified;

- The influence of family members who are not in an operating or ownership position;

- Inter generational goal ambiguity;

- Conflicting roles.

Family businesses have to cope with specific challenges not inherent to non-family businesses. European politicians have started to design and implement institutional structures and support instruments favoring the development of family firms. However, more knowledge is needed about the characteristics and circumstances of family businesses for effectively initiation and further development of a "family business-friendly environment" (Mandl, 2008).

The existing literature in the field of family business research has clearly shown that the objectives of family firms often display a strong preference toward non-economic outcomes in addition to financial performance (Zellweger and Nason, 2008). From a stakeholder viewpoint, this is a natural consequence taking into consideration the presence of many actors and the multiple roles of family members within the same family firm. The concept of performance and value creation becomes incredibly complex, in particular when the chronological dimension is taken into consideration (Colli, 2012). Family businesses struggle, not only with performance and value creation questions, as all firms do in these days of financial crises, but also with family relationships and succession 
issues. Due to the high percentage of family owned businesses they deserve a special attention in order to survive and develop.

Trucker (2011) states that most family business advisers come from legal, accountancy or business advisery professions, without possessing all the skills needed to work successfully with family business clients. He proposes that collaborative working is the way of ensuring that family business clients receive the most effective professional support. Our motivation for the "Family Business in the New Economy: How to Survive and Develop" (FAMBUS) project has built on this observation and considered that an electronic tool available on the internet for diagnosis of problem areas and subsequent advice(s) for self-therapy would support family businesses in their strive for sustainability and thrive.

In order to understand the challenges family businesses meet and the role they play in the new economy an extensive literature review was carried out. Two countries, namely Finland and Greece, with a high percentage of family businesses were selected as representatives for the qualitative and quantitative research carried out on a selected unbiased sample of family businesses in order to deepen the understanding of the particularities family businesses face. Greece is the country in Europe with the highest percentage of family businesses (Kyriazopoulos and SamantaRounti, 2008). Percentages between 52\% (EOMMEX, 2007) and 80\% (Agapitou and Theofanides, 2006) have been mentioned. Similarly with Greece also Finland has a high percentage of family businesses. According to a EU expert group (Stenholm, 2008) 80\% of all Finnish enterprises can be defined as family enterprises when optimistic estimations and a broad definition are used. Nevertheless, the presence of family businesses has been rather visible during the last decade in Finland. The role of family businesses as employers has often been emphasized due to the fact that family businesses employ more than half of the workforce within the private sector and produce $40 \%$ of the total turnover of all businesses.

The main contribution of this study is the development of a model for diagnosis and self therapy (diagnostics - therapy (modernization, adoption to environment, to globalization etc.)), including an electronic tool to be used by family businesses for identification of potential problem areas and potential activities for their solutions. The broad aim is to raise awareness of the challenges and opportunities related to family business context especially from the point of view of success, wellbeing and longevity in the society at large.

\section{BUSINESS TRANSFER: EXAMPLES OF PRACTICAL SUPPORT TOOLS}

All viable organizations are at some point in their existence confronted by executive succession. In many companies, transfers in both leadership and ownership tend to be seen as phases in the life cycle and part of managing continuity. The transfer of a family business is a once-in-a-lifetime event of which the proprietor has little or no experience. It is a complicated matter which concerns many stakeholders and calls for expertise in a wide spectrum of fields.

Haag (2012) proposes that succession is not just about handing the business over from one generation to the next but evolves as family members are socialized, engaged and trained through the daily activities of the family business. She considers that engaging in the family business as part of developing it is fundamentally different from joining because transfer of leadership and/or ownership is needed. She suggests the idea of succession as a purpose in itself and a shift from "taking over" to "being part". However, the succession may not be as smooth as described by Haag (2012). The succession may create considerable conflicts in the family business. 
Various forms of support is provided in different areas from many bodies such as accountants, banks, chambers of commerce, tax experts, lawyers, consultants and academics. Business transfers should be given at least the same degree of importance as start-ups. According to an Austrian research project by the Austrian Institute for Small Business Research, 96\% of successful business transfers survive the first five years after transfer when the chances of survival for start-ups and for the same length of time, are $75 \%$ (Voithofer, 2002).

A reason of major problems in business transfers to the next generation is that the planning for the transfer process has started too late. Raising awareness about the need to prepare for the transfer a long time in advance is the starting point for a successful transfer. Once entrepreneurs have been made aware about the necessity, they need information and support to prepare the transfer (Voithofer and Mandl, 2004). The potential successor needs also information about the process. This type of support should give an overview of what steps need to be taken, what kind of more specific advice is available and where to get it. Below we highlight a number of examples of good practice for supporting the transfer of businesses created in three EU countries, Italy (kit.brunello), Finland (passing the baton) and Netherlands (from single project to a path of overall support) (European Commission, enterprise publications 2003).

"Kit.brunello" is a self-analysis check-up for Small and Medium Sized Enterprises (SMEs), specifically focused on family business transfer processes (Brunello, 2002). This tool is available in five languages and contains 100 questions to help entrepreneurs understand the strong and weak points of the transfer of businesses. Kit.brunello covers not only technical aspects (financial, fiscal, legal, organizational etc) but also emotional, psychological and leadership issues. The Finnish Employment and Economic Development Centers offer a business advice service entitled "passing the baton", that helps to manage the generation shift. This service consider suitable candidates for succession, determines the financial worth of the enterprise, clarifies tax and judicial aspects and accesses the alternative forms of financing. In Netherland the Council of Entrepreneurship in cooperation with a bank and an accountancy firm developed a support structure for succession in family businesses called "from single project to a path of overall support: Towards an integrated method of information and advice on the transfer of family businesses".

A similar support model of diagnostics and self therapy in Greece would help considerably the transfer of family businesses to the next generation especially today when because of the fiscal crisis alternative employment opportunities of the younger family businesses' members are very limited.

\section{RESEARCH METHODOLOGY}

\subsection{Motivation and perspective}

This study is motivated by three important issues, namely:

i. The observation that family businesses have a significant role to play in the strength and dynamism of the European economy and long-term stability. Across Europe around 70$80 \%$ of all enterprises are family businesses and totally they comprise employment around 40-50\% (Mandl, 2008). In Europe the family business sector is dominated by SMEs and particularly by micro enterprises with less than 10 employees. Family businesses are active in all sectors of the economy. Most of the family businesses can be found in traditional and labor intensive sectors. However, a shift towards more modern industries is taking place.

ii. The importance of family businesses in both the Greek and the Finnish economy. Despite the differences in economic structure and culture both Greece and Finland are small countries in the outskirts of Europe with a high percentage of family businesses. Greece 
relies on the service sector and in particular on tourism, whilst Finland counts on a highly industrialized manufacturing sector and is one of the economically and politically most stable countries in the world. Culturally Finns are known to be hard-working with an introverted nature and direct communication style, compared to Greeks who are more outgoing and highly value personal relationships and networks.

iii. The need for in-depth research about the dynamics of family businesses, the difficulties they face (strategy, succession, internal conflicts etc.) and factors influencing their survival (endurance) and sustainability. Despite the fact that family businesses contribute significantly to economic activity and employment, comparatively little research has been carried out to identify the needs, aspirations and challenges of European family businesses. The family businesses involve three overlapping elements that make them different from other types of business, namely the family, the business, and the ownership. Although many of the challenges family businesses face, also concern SMEs in general, some affect family firms more specifically, and others are exclusive to only them. Some challenges stem from the environment in which the firms operate (inheritance, taxation etc.), others are connected to the family firm's internal matters, such as balancing the business, family and ownership aspects, succession and internal conflicts between family members and ascertaining professional business management. Private and personal interests may be transferred to the company and vice versa. As the same persons may have different overlapping roles in the family business it is not easy to find balance at times.

\subsection{Research Question}

The research question in this study is to what degree the family businesses are similar or different in Finland and in Greece.

To answer this we need to know:

i. Percentage of family businesses in Finland and in Greece;

ii. Type of family businesses in Finland and in Greece;

iii. Characteristics of family businesses typical in both countries.

Some other questions arise:

i. What are the factors that influence the creation and sustainability of family businesses in respective country?

ii. What are the similarities and the differences of family businesses in the two countries?

iii. What are the success factors of family businesses in respective country?

In addressing these questions certain measures and interim models were developed to improve understanding and to form the basis for the assessment of family business characteristics both in Finland and in Greece. The data has been correlated with family business characteristics drawn from the literature. The results allow for the identification of a number of cultural factors that have a bearing on the successful functioning and operation of family businesses both in Finland and in Greece.

\subsection{Research objectives and hypothesis}

Very little is written about family businesses, especially regarding family business characteristics in Finland and in Greece. The literature also provides contradictory evidence regarding the performance of family-owned firms identifying four main issues influencing the performance of a family business, namely industry, firm governance, firm characteristics and management (founder) (Dyer, 2006). 


\section{Objectives}

The main objectives in this study are to:

i. identify characteristics that have a bearing on successful implementation and operation of family businesses. In order to investigate the research question the family business characteristics have been grouped into two categories: business characteristics and family characteristics. The characteristics are divided in six groups aiming to help identify strengths and areas in need of improvement.

ii. construct a Diagnosis and Self Therapy model which will take family and business factors into consideration. The model will aim to diagnose potential problems and to propose solutions.

iii. create an electronic tool/instrument of the Diagnosis and Self Therapy model.

iv. verify the model and to test the electronic tool.

\section{Hypothesis}

According to the Oxford English Dictionary a hypothesis is «a supposition which serves as a starting point for further investigation by which it may be proved or disproved». The area of investigation has to be mapped out and limits have to be drawn on the topic. With the topic narrowed the hypothesis formation becomes easier. A hypothesis proposes a relationship between two or more variables according to Hoover (1992).

Following the motivation and the research question the hypothesis in this research derives:

'The family businesses face similar challenges independently of country of origin'.

Two variables are identified: the family and the business.

Four distinct orientations stemming from the relationship between the two variables are observed in the literature (Ward 1987) and depicted in the FAMBUS typology in figure 1:

\section{Figure 1 The FAMBUS Typology}

Family Influential

\begin{tabular}{|c|c|}
\hline $\begin{array}{c}\text { Family first } \\
\text { enterprises }\end{array}$ & $\begin{array}{c}\text { Family-Business } \\
\text { Balance }\end{array}$ \\
\hline Agile & Business first \\
enterprises & enterprises \\
\hline
\end{tabular}

Business insignificant Business influential

- Family first enterprises: family goals take precedence over business goals;

- Business first enterprises: business goals take precedence above everything else;

- Balance between family and business: Family Business enterprises that seek to balance the family and the business goals;

- Agile Enterprises: without a clear focus neither on family nor on business goals.

Research indicates that family businesses with common clear goals on one or the other orientation tend to perform better than family businesses without clear goals (Dyer, 2006). The third orientation, where family businesses constantly seek equilibrium between the family and the business goals, is the most challenging, but also the most rewarding when a successful balance is achieved. The fourth 
orientation is consuming and requires vigilance, flexibility and agility. The family business needs to be alert and meet new requirement in a lean and swiftly manner. Basco and Pérez Rodriguez (2009) found that ambidextrous family businesses perform better both on the family and the business dimensions.

\subsection{The contribution of the study}

The creation of the FAMBUS Diagnosis and Self Therapy model is based on the results of a quantitative study (a survey comprising an on-line structured questionnaire completed by 200 Finnish and Greek family businesses) and qualitative study (personal site visits and interviews comprising 20 interviews in both Finland and Greece) for obtaining deeper understanding of the research problem and to support the design of the FAMBUS Diagnosis and Self Therapy model. The first phase included the qualitative study carried out by using a semi-structured interview instrument that triggered the interviewees to freely express their opinions. The interviews were recorded and analyzed for identification of important issues not obvious to the interviewers in the first place. When such issues were identified they were discussed by the research team and inserted into the instrument for validation and verification by subsequent interviewees. This kind of research process eliminated potential biased interview questions. Correlations and parallels were also drawn to the literature and in particular to characteristics of family businesses in Greece and Finland, which both are small periphery countries, members of the EU, where family businesses possess a dominant role in their economies. However, the business structure and hierarchy are rather different in the two countries, as well as the business conduct and culture. The comparative analysis is original and unique and is anticipated to add to the existing knowledge in the field. The parameters, drawn from the qualitative and quantitative study are grouped and presented in paragraph 3.1. These parameters are the backbone of the diagnosis and self-therapy model. However, a deeper analysis of the outcomes of the qualitative and quantitative study is out of scope in this paper, which mainly concentrates on the need of a diagnosis and self-therapy model and its description. Other publications include Siakas et al. (2014a, 2014b, 2014c, 2013), Vlachakis et al. (2014, 2013a, 2013b), Vassileiadis (2013) and Adamidou et al. (2012).

The results of the study are disseminated directly to the participating family businesses through different streams of information, such as local media and branch interest establishments. The use of social media, both as a meeting and communication platform for involved partners and for viral marketing, is also a contemporary and novel diffusion technique anticipated to bring stakeholders together for knowledge sharing and potential future collaboration.

\section{THE FAMBUS DIAGNOSIS AND SELF THERAPY MODEL}

When dealing with the two separate and often opposing systems of the business and the family, life in a family business can get somewhat chaotic. It is advantageous to have assistance in navigating through the labyrinth of emotions and critical incidents which can threaten the well being of both the family and the business.

Table 1 shows a table that may help to clarify and distinguish between the family and the business related goals being pursued by the family business. In order to understand the degree of alignment between the key stakeholders on desirable goals and perceived performance on the family and the business dimensions it would be helpful to ask each key stakeholder of the family business to provide information for this table. The performance position of the firm signals whether the issues to be looked into more deeply lie more on the family or the business side of the family business. 
Table 1 Family Business Performance (Sharma et al. 2013).

\begin{tabular}{|c|c|c|c|c|c|c|c|c|}
\hline & & \multicolumn{3}{|c|}{$\begin{array}{c}\text { Importance of } \\
\text { Goals }\end{array}$} & \multicolumn{3}{|c|}{ Performance } & \multirow[b]{2}{*}{\begin{tabular}{|c|} 
Overall \\
Performance \\
\end{tabular}} \\
\hline & & High & Medium & Low & High & Medium & Low & \\
\hline \multirow{9}{*}{ 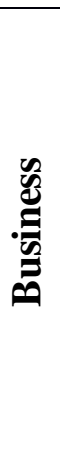 } & Growth in sale & & & & & & & \\
\hline & Growth in market share & & & & & & & \\
\hline & Return on equity & & & & & & & \\
\hline & Return on total assets & & & & & & & \\
\hline & Profit margin on sales & & & & & & & \\
\hline & Ability to fund growth from profits & & & & & & & \\
\hline & Growth in number of employees & & & & & & & \\
\hline & Employee turnover & & & & & & & \\
\hline & $\ldots \ldots \ldots$ & & & & & & & \\
\hline \multirow{6}{*}{ 㾸 } & Family Harmony & & & & & & & \\
\hline & Family wealth & & & & & & & \\
\hline & $\begin{array}{l}\text { Growth in family's human capital } \\
\text { (education, experience) }\end{array}$ & & & & & & & \\
\hline & Development of next generation of family & & & & & & & \\
\hline & $\begin{array}{l}\text { Family's reputation in } \\
\text { the community }\end{array}$ & & & & & & & \\
\hline & $\ldots \ldots \ldots \ldots$ & & & & & & & \\
\hline
\end{tabular}

Most SMEs, where most family businesses belong, have an informal management structure and management style standard without specific policies and practices (Schwerzler, 2011). When it comes to conflicts of interest in family businesses, Schwerzler believes these matters are more difficult to resolve, because there are three levels of interests, namely family issues, business issues, and ownership issues. He considers that every family business is unique and complex in its own way, so 'boiler plate solutions don't always work'. We agree with this notion. However, the FAMBUS Diagnosis and Self Therapy model is a tool for creating awareness in family business members of potential problem areas. It also will propose some advices for consideration and deeper problemsolving mechanisms by the family members. We can say that the FAMBUS Diagnosis and Self Therapy model triggers family business members to find solutions to potential problems through their identification and the suggestions of therapy. The tool will trigger family business members to dig deeper in the problems and to investigate potential solutions suitable for the specific family business context. The model will to some degree act as a coach or consultant that tries to improve relationships.

\subsection{Description of the FAMBUS Diagnosis and Self Therapy model}

The following potential problem areas are derived mainly from the qualitative and quantitative study, but also from the extensive literature review of family businesses that was the base for the creation of the research instruments. Partial results from the study are published in Siakas et al. (2014a, 2014b, 2014c, 2013), Vlachakis et al. (2014, 2013a, 2013b), Vassileiadis (2013) and Adamidou et al. (2012). 
The potential problem areas are grouped into six essential elements aiming to help identify strengths and areas in need of improvement, and are as follows:

- Strategy

○ Level of formality;

○ Communication of strategy (with family members, administrative personnel and other employees);

○ Decision making process.

- Administration

- Allocation of roles and responsibilities;

- Predefined mechanisms (processes, problem solving and cash-flow);

- Decision making (top-down - council - influence of family members not working in family business);

○ Use of external consultants.

- External issues influencing the family business thrive

○ The motives for the creation of your family business (pull - push);

○ The business/work climate in the period the family business creation;

- Relationships with the state and its services (taxation, bureaucracy, corruption, unclear responsibilities between different state organizations);

- Support from (state) organizations supporting family businesses;

○ Use of Information and Communication Technologies (ICTs) \& Knowledge in using ICTs;

○ Use of marketing tools \& skills in using marketing tools.

- $\quad$ Succession

- Existing plan for succession.

- Criteria for choosing successor;

- Agreement of plan by other family members;

- Successor(s) suitability;

- value - stability - change;

- experience in the family business / other experience;

- education / training.

- Participation in Networks. A network is "a specific type of relation linking a defined set of persons, objects or events" (Donckels \& Lambrecht, 1995). Networks represent several advantages to those firms that are inside the network:

$\circ$ exchanging knowledge and gaining experience;

o identifying new opportunities;

○ participation in clusters;

○ access to scarce resources (e.g. financial capital, reputation);

○ trigger for international business activities;

- building capabilities for international operations;

- facilitation of internationalization of operations.

- Conflicts. Many family businesses circle around conflict in one or both reference systems, the family or the business. Researchers have identified three forms of conflict-task, process and relationship (Eddleston 2014). Potential conflicts within a family business are:

○ The way decisions are taken;

○ The wage-levels of family members working in family business;

- Employment of relatives in-law;

○ Generation gap; 
- Gender working in family business;

- Level of education of family members working in the family business;

- Different perceptions of how things should be done;

$\circ$ Different perceptions of the future of the family business.

The FAMBUS Diagnosis and Self Therapy model aims to engage in the following issues:

- Conflicts: Helping family businesses deal with conflicts in a more productive and healthy manner.

- Communication problems: Helping family business members understand their own communication style and the styles of others in order to adapt accordingly.

- Problems involving anger and hurt: Helping family business members learn how to forgive themselves and others so they can move forward.

- Long term goals: Providing encouragement and accountability so family business members can sustain their energy and focus on strategic long-term issues.

- Vision: Emphasizing the importance of a vision for the family and the business that all family members agree upon.

- Behavioural styles and motivations: Raising awareness of different behavioural and motivation styles and their impact on relationships.

- Governance structure: Raising awareness of suitable governance structures in different types of business. Governance of family firms is more complex than the ownership centred governance in their non-family counterparts (Gersick and Feliu, 2014). Progressive family firms often use a combination of governance structures or bodies.

- Roles and Responsibilities: Clearly defining roles and responsibilities.

- Network development: Networks are identified to be a prerequisite for profit and development (Johansson and Matsson, 1998) and involve the conduct of business among those firms that are inside the network. The ability to grow internationally depends on building network relationships abroad (Graves and Thomas, 2008). Family Businesses have been identified to have a limited number of external network ties in comparison to non-family firms (Graves and Thomas, 2008). They seem to be reluctant to form networks with foreign partners (Pukall and Calabrò, 2013), eventually as a consequence of their strong internal family related networks (Arregle et al., 2007).

- Holistic approach: Collaboration with consultants in the family business aims to ensure a holistic approach.

Raising awareness can cover many different activities: anything that involves people understanding, learning or doing something new; visioning the future; working out how to change something in their lives; or talking to someone else about what they have done - all are part of the process of raising awareness about the need for transition/change/improvement.

Schwerzler (2011) suggests seven rules for family businesses to follow in order to minimize potential problems:

1. Family Members on the payroll: Family members should not be put on the payroll if they are not working in the company or if they cannot make a real contribution to the business. It is hard to be objective about hiring relatives, especially own children. An assessment of strengths and weaknesses of family members should be done before they are brought into the business. Also clear rules and role responsibilities should be spelled out (Green and HilburtDavis, 2009). Schwerzler gives the following advices:

i. Make sure that everyone has a role and responsibilities that are spelled out and are very clear;

ii. Establish the title, job function, and compensation for each person; 
iii. Make sure that you have the same performance reviews for family and non-family employees;

iv. Think twice about offering a contract to a supplier who is a relative;

v. Award contracts based on merit and contribution.

2. Two classes of employees: Be careful not to create two classes of employees-family vs. nonfamily. Do not to show family members special treatment. Be aware that, in a small or family-owned business, special favors given to family members and friends de-motivate employees and set a bad example. Avoid making non-family members to feel like a raise or promotion is out of their reach because they are not part of the family members.

3. Abuse of family relationships: Do not either reward or punish someone because they are a relative with whom you have personal history.

4. Communication with employees: Communicate honestly and openly with employees. Do not keep it a secret or hide the fact that you have relatives or friends working for you, otherwise when it eventually comes out, and it will, you will appear like you were being deceitful. The ability to have an effective communication with all members of the organization is critical.

5. Confusion of family decisions and business decisions. You should avoid letting family members borrow company vehicles or allowing them to ask the company's IT person to set up their home offices. Do not pass off personal expenses, such as family vacations, as business expenditures.

6. Healthy boundaries between family and business: Establish healthy boundaries between family and business. This especially applies to co-preneuers (husband-and-wife teams).

Running a business together with your spouse is a balancing act. Agree and adhere to some kind of system. In general, it should be a rule not to work with other family members outside of the office.

7. Use family councils to address family matters. Some family members will share the same values but not the same vision. One sibling may want to grow the business and keep it privately owned while another sibling may want to sell it or take it public. A family council comprises members who may be owners but not company employees. They meet monthly, quarterly and/or annually for the strategic planning of the business over the next year to next 10 years. The more dysfunctional the family is the smaller the group to begin with. The council does not micro manage the business but addresses family issues or concerns relative to the business. If a family member is working in the business but needs a car this is something that the family council will address. Typically one family member of the council is appointed to report to board members or shareholders. Family business experts concede that family ownership does have its privileges. But you have to really be careful and run the business in such a way that it is fair. It is transparent and it does not hurt the company morale.

\subsection{Creation of an electronic tool (instrument)}

The FAMBUS Diagnosis and Self Therapy on-line tool is an electronic instrument to be used by the family businesses. The tool can be used to better understand family business characteristics and indicators, and reflect on all aspects important for thrive. The FAMBUS Diagnosis and Self Therapy on-line tool firstly makes an assessment of the current situation in the family business and provides practical, real-world strategies, tips, case studies, examples, and reflection questions in order to guide and support the family business to cultivate a culture of learning in the family business. It is called a "tool" because it is meant to help the family business grow, and it designed to be tailored according to the needs of the family business. How it is used depends on the needs, strengths, challenges, maturity, and capacity of the family business. It is not meant to be used as a device for judging the family business as "good" or "bad." The tool is intended to be used rather as a guide for making every part of the family business the best that it can be. 
The FAMBUS Diagnosis and Self Therapy on-line tool is organized around six essential elements, all of which come from the literature review and evidenced-based practice. Each of these methods can help identify strengths and areas in need of improvement.

\section{DISCUSSION AND CONCLUSIONS}

In the 80s the family firm adviser emerged as a recognized profession (Astrachan \& McMillan, 2006). Since then multiple advisery roles have surfaced that provide support and act as resources for family firms. These advisers are grouped under three categories: formal advisers, informal advisers, and family firm boards (Strike, 2012). Strike (2012) carried out a review on family business advisers. He states that there are limited studies that establish links between advising activities and family firm outcomes and that there is little evidence concerning when and to what extent advisers succeed in influencing family firms. Moreover the effect of the advice on firm performance can be discussed. There is an assumption that there is a positive association between advisers and positive outcomes, but likewise there is a likelihood that advice also can result in negative outcomes. In addition consulting advisers may be rather expensive.

Due to the importance of the family businesses in today's turbulent economy we strongly believe that family businesses need some kind of support and help to overcome their potential problems and a meeting point where they can meet other family businesses.

This is also rather important for the follow reasons (Vlachakis et al., 2013a):

- Many family businesses lack a formal education to run their businesses. The founders of many family firms are self-created entrepreneurs. They founded their own business to secure work for themselves and for the members of their family. They operate more under conditions of "necessity (push) entrepreneurship" and less of "opportunity (pull) entrepreneurship";

- Family businesses tend to have greater resistance toward the impacts of the financial crises due to the family ties;

- There is a low level of extroversion due to the small size of the firms and the low availability of funds.

By providing a tool that identify problem areas (raising awareness) and propose some basic advices the family businesses can start digging on their own into their problems and find solutions. The social media meeting point in the project web-page will also help family businesses to meet other family businesses with similar problems or even potential partners for cluster building and potential customers and contacts.

The main results stemming from the FAMBUS Diagnosis and Self Therapy model are expected to be very important for family businesses that want to find an easy and cheap way of diagnosing potential problem areas and receiving improvement proposals instead of hiring expensive business consultants. Subsequently the web-page for the model/tool will also serve as a meeting/communication social media platform/forum for family businesses and other interested parts as well as a dissemination point for authorities, industry and academia.

Viral marketing (word-of mouth) techniques will be used to spread the information of the project and subsequent activities. Direct financial advantages may be difficult to be measured, but if the project is successful and several family businesses find the advices useful then the direct/indirect financial benefits will not only be evident for the family business themselves but will also have a direct financial consequence on broader local, as well as national level. 


\section{ACKNOWLEDGMENTS}

The work presented in this paper has been partially supported by the activities in the project "Family Business in the New Economy: How to Survive and Develop (FAMBUS)", co-funded by the E.U. (European Social Fund) and national funds, action "Archimedes III - Funding of research groups in T.E.I.". This publication reflects only the views of the authors, and the Commission cannot be held responsible for any use, which may be made of the information contained therein. 


\section{REFERENCES}

Adamidou, E., Siakas, K., Naaranoja, M. (2013). How can innovations in computer sciences and management reinforce family businesses towards the challenges of the new economy?, 8th Annual South East European Doctoral Student Conference Programme, Research Track 1: Enterprise Innovation \& Development, 16 - 17 September 2013

Agapitou, C. and Theofanides, F. (2008). Overview of Family Business Relevant Issues Country Fiche Greece, UNIVERSITY OF PIRAEUS RESEARCH CENTER, in the framework of the study "Overview of Family Business Relevant Issues" accessed 26/11/2012; http://ec.europa.eu/enterprise/policies/sme/files/craft/family_business/doc/familybusines_count ry_fiche_greece_en.pdf)

Arregle, J.-L., Hitt, M.A., Sirmon, D.G. and Very, P. (2007). The development of organizational social capital: Attributes of family firms, Journal of Management Studies, Vol. 44 No. 1, pp. 73-95.

Astrachan, J. H., \& McMillan, K. S. (2006). United States. In F. W. Kaslow (Ed.), Handbook of family business \& family business consultation: A global perspective, pp. 347-363.

Binghamton, NY: International Business Press.

Basco, R., and Perez Rodriguez, M. J. (2009) Studying the Family Enterprise Holistically: Evidence for Integrated Family and Business Systems. Family Business Review Vol. 22, No. 1, pp. 82-95.

Brice, W. D., \& Richardson, J. (2009). Culture in family business: A two-country empirical investigation. European Business Review, 21, pp. 246-262.

Brunello T. (2002). The Kit.brunello-based Laboratorium, in European Seminar on Transfer of Businesses Final Report, accessed 02.06.2014 available at http://ec.europa.eu/enterprise/policies/sme/files/support_measures/transfer_business/vienna_tra nsfer_seminar_final_report_en.pdf.

Cramton, C.D. (1993). Is rugged individualism the whole story? Public and private accounts of a firm's founding, Family Business Review, Vol. 6, No. 3, pp. 233-61.

Colli, A. (2012). Contextualizing Performances of Family Firms: The Perspective of Business History Family Business Review, Vol. 25, No. 3, pp. 243-257.

Danes, S.M., Lee, J., Stafford, K. and Heck, R.K.Z. (2008). The effects of ethnicity, families and culture on entrepreneurial experience: an extension of Sustainable Family Business Theory, Journal of Developmental Entrepreneurship, Vol. 13 No. 3, pp. 229-68.

Danes, S.M., Stafford, K., Haynes, G. and Amarapurkar, S. (2009). Family capital of family firms: bridging human, social, and financial capital, Family Business Review, Vol. 22 No. 3, pp. 199215.

Donckels, R., and Lambrecht, J. (1995). Networks and small business growth: an explanatory model, Small Business Economics, Vol. 7, No. 4, pp. 273-289.

Dyer, W. G. (2006). Examining the "Family Effect" on Firm Performance, Family Business Review 19, pp. 253-273.

Eddleston, K., and Kellermanns, F. W. (2007). Destructive and Productive Family Relationships: A Stewardship Theory Perspective. Journal of Business Venturing, Vol. 22, No 4, pp 545-565.

EOMMEX (2007). The Hellenic Organization of Small Medium Sized Enterprises \& Handicraft S.A.

European Commission, Enterprise Publications (2003). Helping the transfer of businesses: A good practice guide of measures for supporting the transfer of businesses to new ownership, Office for Official Publications of the European Communities, ISBN 92-894-5243-9, accessed 02.06.2014, available at http://bookshop.europa.eu/en/helping-the-transfer-of-businesses-pbNB4702979/.

Gersick, K. E., and Feliu, N. (2014). Governing the Family Enterprise: Practices, Performance, and Research. In SAGE Handbook of Family Business. Edited by Melin, L., Nordqvist, M., and Sharma, P. London, U.K., Sage Publications.

Graves, C., and Thomas, I. (2006). Internationalization of Australian family businesses: A managerial capabilities perspective, Family Business Review, Vol. 19, No. 3, pp. 207-224. 
Green, J. L., and Hilburt-Davis J. (2009). Consulting to Family Businesses. Alpha Books/The Penguin Group.

Haag, K. (2012). Rethinking family business succession: From a problem to solve to an ongoing practice, JIBS Dissertation Series No. 082, Jönköping International Business School, Sweden.

Heck, R.K.Z. and Stafford, K. (2001). The vital institution of family business: economic benefits hidden in plain sight, in McCann, G.K. and Upton, N. (Eds), Destroying Myths and Creating Value in Family Business, Stetson University, Deland, FL, pp. 9-17.

Heck, R.K.Z. and Trent, E.S. (1999). The prevalence of family business from a household sample, Family Business Review, Vol. 12, No. 3, pp. 209-24.

Hoover, K.R. (1992). The Elements of Social Scientific Thinking, St.Martins Press Inc.

Johanson, J., and Mattsson, L-G. (1988). Internationalization in industrial systems - a network Approach, in Hood N. and Vahlne J-E., Strategies in Global Competition, New York: Croom Helm, pp. 287-314

Kyriazopoulos, P. and Samanta-Rounti, I. (2007). Problems and Opportunities of the Relationships between the First and Second Generation of Self-Managing Family Businesses, 7th International Congress Marketing Trends 25-26 January Venice, Italy (accessed 26/11/2012; www.escp-eap.net/conferences/marketing ).

Lambrecht J. and Donckels R. (2006). Towards a Business Family Dynasty: A life long, continuing process. In the Handbook of Research on Family Business, edited by Poutziouris P., Smyrnios K. and Klein S., Edward Elgar Publishing Ltd, UK, pp.388-401.

Lansberg I. (1988). The Succession Conspiracy. Family Business Review, Vol. 1, No. 2, pp.119-143.

Mandl, I. (2008), Overview of Family Business Relevant Issues - Final Report, Vienna. Austrian Institute for SME Research

Michael-Tsabari, N., and Lavee, Y. (2012). Too Close and Too Rigid: Applying the Circumplex Model of Family Systems to First-Generation Family Firms. Journal of Marital and Family Therapy Vol. 38. Iss 1, pp.105-116.

Ponzetti, J. J. (2003). International Encyclopedia of Marriage and Family, 2nd ed., Macmillian Reference, New York, NY

Pukall, T. J., and Calabrò, A. (2013). The Internationalization of Family Firms: A Critical Review and Integrative Model, Family Business Review, pp. 1-23.

Rogoff, E.G. and Heck, R.K.Z. (2003). Evolving research in entrepreneurship and family business: recognizing family as the oxygen that feeds the fire of entrepreneurship, Journal of Business Venturing, Vol. 18 No. 5, pp. 559-66.

Schwerzler, D. (2011). Rules of conduct for family businesses. Available at http://www.inc.com/guides/201102/7-rules-of-conduct-for-family-businesses.html.

Sharma, P., Blunden, R., Labaki, R., Michael-Tsabari, N. and Rivera J. (2013) Analyzing Family Business Cases: Tools and Techniques. Case Research Journal, Vol. 33, Iss. 2, pp. 1-20.

Siakas K., Vassiliadis S., Siakas E. (2014a). Financial Performance in Times of Turmoil: An Examination of the Role of Family Ownership, South East European Journal of Economics and Business (Submitted).

Siakas K., Naaranoja M., Vlachakis S. and Siakas E. (2014b). Family Businesses in the New Economy: How to Survive and Develop in Times of Financial Crisis, Elsevier - Procedia Finance and Economics (Accepted).

Siakas K. V., Belidis A., Siakas E (2014c). Social media marketing for improved branding and valorisation in small family businesses, International Conference on Contemporary Marketing Issues (ICCMI 2014), 18-20 June, ISBN: 978-960-287-145-4, Athens, Greece, pp. 764 - 772.

Siakas, K., Naaranoja, M., Vlachakis, S., Siakas, E. (2013). Family Businesses in the New Economy: How to Survive and Develop. 5th International Conference 'The Economies of Balkan and Eastern Europe Countries in the changed World', EBEEC 2013, Istanbul, Turkey, 9-12 May.

Stenholm, P. (2008). Overview of Family Business Relevant Issues Country Fiche Finland, Turku School of Economics, TSE Entre, in the framework of the study "Overview of Family Business 
Relevant Issues" accessed 26/11/2012;

http://ec.europa.eu/enterprise/policies/sme/files/craft/family_business/doc/familybusines_count ry_fiche_finland_en.pdf.

Strike V.M. (2012). Advising the Family Firm: Reviewing the Past to Build the Future, Family Business Review, Vol. 52, No. 2, pp. 156-177.

Sundaramurthy, C., \& Kreiner, G. E. (2008). Governing by managing identity boundaries: The case of family businesses. Entrepreneurship Theory and Practice, 32, pp. 415-436.

Tucker, J. (2011). Keeping the business in the family and the family in business: "What is the legacy?"Journal of Family Business Management, Vol. 1 No. 1, 2011, pp. 65-73.

Villalonga, B., \& Amit, R. (2010). Family control of firms and industries. Financial Management, 39, pp. 863-904.

Voithofer, P. (2002). Business Transfers and Successions in Austria, in European Seminar on Transfer of Businesses Final Report, accessed 02.06.2014, available at http://ec.europa.eu/enterprise/policies/sme/files/support_measures/transfer_business/vienna_tra nsfer_seminar_final_report_en.pdf.

Vlachakis, S., Siakas K., Belidis A. (2014). Succession in small-medium sized family businesses: A study of next generation marketing graduates' contribution to the family business, International Conference on Contemporary Marketing Issues (ICCMI 2014), 18-20 June, ISBN: 978-960-287145-4, Athens, Greece, pp. 263 - 271.

Vassileiadis S. (2013). The Greek family businesses and the succession problem, EBEEC Conference, 9-12 May, Istanbul.

Vlachakis, S., Siakas, K., Naaranoja, M. (2013a). Family Business in Greece, Investigation of the basic problems, 8th Annual South East European Doctoral Student Conference Programme, Research Track 1: Enterprise Innovation \& Development, 16 - 17 September.

Vlachakis, S., Siakas, K., Naaranoja, M. (2013b). Family Businesses: A Study Regarding the Use of Marketing Tools by Small-Medium Family Businesses in Greece, G.M. Papadourakis, I. lazaridis, D. Paschaloudis (eds). New Horizons in Industry, Business and Education (NHIBE 2013), Chania, Crete, 29-30 August, ISBN. 978-960-99889-6-4, pp.265-272.

Voithofer, P., and Mandl, I. (2004). Transfer and succession in Austrian family firms. KMU Forschung Austria. Austrian Institute for SME Research.

Ward, J. (1987) Keeping the Family Business Healthy: How to Plan for Continuing Growth, Profitability, and Family Leadership. San Francisco, CA: Jossey-Bass.

Zachary, R.K. and Mishra, C.S. (2011). The future of entrepreneurship research: calling all researchers, Entrepreneurship Research Journal, Vol. 1 No. 1, pp. 1-13, available at: www.bepress.com/erj/vol1/iss1/1/.

Zachary R.K. (2011). The importance of the family system in family business, Journal of Family Business Management, Vol. 1 No. 1, pp. 26-36.

Zellweger, T. M., and Nason, R. S. (2008). A stakeholder perspective on family firm performance. Family Business Review, 21, 203-216. 